ISSN: 2581-8341

Volume 04 Issue 12 December 2021

DOI: 10.47191/ijcsrr/V4-i12-19, Impact Factor: 5.825

IJCSRR@ 2021

www.ijesrr.org

\title{
Strategy Development for Survival \& Growth of MRO Company during \& Post Covid-19 Pandemic (Case Study: GMF Aeroasia)
}

\author{
R. Rendy Purwidyaputra \\ School of Business and Management, Institut Teknologi Bandung
}

\begin{abstract}
Indonesian Aviation Market 2020 was predicted to grow around 7.0\% compared to 2019. It gave Indonesian MRO industry an optimism at first, at least in the beginning of the year, before WHO declared COVID-19 pandemic in March 2020. The COVID-19 pandemic has a dire impact on the aviation \& MRO industry. As of July 2021, flights still haven't reached 50\% compared to pre-COVID era. Many MRO companies, including GMF AeroAsia, must face an unprecedented situation that caused the market to shrink significantly, and enter the financial distress zone. Several initiatives have been taken by the company. However, with the protracted pandemic conditions and the uncertainty of Indonesian Aviation Market recovery, further strategies are needed to survive and growth. This study aims to analyze the company and develop a strategy based on 2 stages, namely the retrenchment phase and the recovery phase. The retrenchment phase will focus on the survival strategy, while the recovery phase will focus on the growth strategy using scenario planning because the future is still uncertain. From the analysis and interviews, several initiatives and strategies for survival and growth were developed. Several initiatives for survival include headcount cuts, operational efficiency, product elimination, liquidation \& divestment, equity for debt swaps, and renegotiate with lenders. While the growth strategy was developed based on 4 scenarios, namely Flying Through Thunderstorm, Flying with Engine Failure, Flying with Broken Wings, and Flying Zig-Zag.
\end{abstract}

KEYWORDS: Financial Distress, GMF Aeroasia, Aviation, MRO, Pandemic, Survive, Growth, Scenario Planning

\section{INTRODUCTION}

PT Garuda Maintenance Facility Aero Asia Tbk is known as the aircraft Maintenance, Repair, and Overhaul (MRO) company with various acknowledgments from international institutions. The Company owns multiple certifications for aviation MRO from domestic and international authorities, including from the Indonesia DGCA, Federal Aviation and Administration (FAA) and European Aviation Safety Agency (EASA). Currently, the largest shareholder is Garuda Indonesia with $89.1 \%$ ownership, followed by the public with $10 \%$ ownership, and PT Aero Wisata with $0.9 \%$ ownership. Garuda Indonesia itself is an Indonesian flag carrier airline with government ownership of $60.5 \%$. In 2020, when the pandemic hit the aviation and MRO industry, GMF recorded revenue of 254 MUSD, or down more than 50\% compared to 2019. In the same year net profit plunged to minus 329 MUSD. As of July 2021, International \& Indonesian flights still haven't reached 50\% compared to pre-COVID era. The cashflow management became very challenging because fixed cost is quite significant. Several efficiency measures have been taken by GMF. However, with the protracted pandemic conditions, further strategies and execution are needed to survive.

Furthermore, the future is still unclear. Although IATA has stated that aviation industry will be $100 \%$ recovered by 2023 , several consultants have mixed views. For example, an aviation consultant developed 3 scenarios for post-pandemic conditions based on the speed of vaccine distribution, the wave of outbreaks, and the economic recovery. In the best scenario it is predicted that flight conditions will return to pre-covid (2019) conditions in Q2 2022, while in the worst scenario is in Q1 2024.

This indicates that there is high uncertainty in the recovery of world aviation conditions, including MRO as a supporting industry. No one knows for sure, when the pandemic will end and the number of air transportation passengers will return to the same as in the precovid period in 2019. In the midst of uncertainty and rapid change, GMF must be able to prepare a further strategy to survive and growth.

\section{LITERATURE REVIEW}

Financial Distress and Altman's Z Score

Financial distress is defined as a late stage of corporate decline that precedes more cataclysmic events such as bankruptcy or liquidation (Platt \& Platt, 2002). In some literature, there are several terms related to financial distress, including failure, insolvency, 


\section{International Journal of Current Science Research and Review}

ISSN: 2581-8341

Volume 04 Issue 12 December 2021

DOI: 10.47191/ijesrr/V4-i12-19, Impact Factor: 5.825

IJCSRR@ 2021

www.ijcsrr.org

bankruptcy, and default (Altman \& Hotchkins, 2006). There are many tools that can be used to determine whether a company is in the distress category or not. One that is widely used is the Altman Z Score.

Altman Z Score is a financial analysis model developed by Edward I. Altman in 1968 for identifying corporate financial performance related to the potential of financial distress or bankruptcy. Several improvements were made over time, including adjustments for companies operating in emerging markets (called Emerging Market Score - EMS; otherwise known as Z" Score).

\section{Survival Strategy}

There is a lot of literature that discusses survival strategy or turnaround strategy in times of distress. In general, turnaround activities for corporate distress are divided into several parts, namely Operational, Managerial, Portfolio, and Financial (Schweizer \& Nienhaus, 2017). This research will focus on Portfolio and Financial aspects. There are 2 interesting literatures related to survival activities that fall into the portfolio and financial categories. The first is research related to Turnaround. Robins \& Pearce (1992) conducted empirical research on companies that were experiencing distress and trying to survive by doing a turn around which was divided into 2 stages of processes: retrenchment and recovery. The suggestions for Retrenchment Phase are: Operational efficiency, Head count cuts, Liquidation, Divestment, and Product elimination.

The next interesting discussion is about the debt ratio. A high debt to assets ratio shows that most assets of the company are financed by debts that triggers the occurrence of corporate financial distress as the company is suffering financial burdens (Nurhayati, Mufidah, \& Kholidah, 2017). Financial distress occurs when a company fails or is unable to satisfy the obligations to the creditor because it is experiencing shortages of funds. This unfavorable condition makes total liabilities greater than the total assets, and it cannot achieve the company's economic goals of profit (Darmawan \& Supriyanto, 2018). In order to analyze and find strategies to reduce debt ratio, a framework Aswath Damodaran is used, namely the framework for Getting to The Optimal.

The aswath damodaran framework provides a clear line of thought based on several parameters that are answered in stages. In general, this framework groups companies into 2 categories, namely overlevered or underlevered. If the actual debt ratio is above the optimal debt ratio, then it is overlevered, and vice versa. Overlevered means that the company has too high a debt ratio so that it must reduce its debt through several activities such as equity for debt swaps, sell assets and pay off debt, take good projects with new equity or retained earnings, or pay off debt with retained earnings. Underlevered means the company must add debt to be optimal. Some of the activities that can be carried out are debt/equity swaps, borrow money, pay dividends and buy back stocks.

\section{Scenario Planning}

Scenario planning is a process that stimulates imaginative, creative thinking to better prepare an organization for the future based on major forces that might move the world in different directions (Garvin \& Levesque, 2006). The advantage of scenario planning is that it can anticipate high uncertainty so that it is very relevant to be applied in conditions of the business environment that often changes. Instead of designing a strategy for one possible future, scenario planning encourages to explore many possibilities in the future (multi scenarios) based on the factors that have the highest uncertainty and have the greatest impact on the company. There are several components in designing Scenario Planning including Key focal Issues, Driving Forces, Critical Uncertainties, Scenario Framework, Scenarios, Narratives, Early Warning Signals, Implications, and Options. And there are 5 stages in the scenario planning process, namely Orientation, Exploration, Scenarios Creation, Option Consideration, and Integration.

\section{METHODOLOGY}

The methodology in this research is through data collection from both primary and secondary data sources. The primary data will be collected through observation and interview with top management of the company, as well as the key person from external. The secondary sources are based on literature reviews, company annual report, online news portal, and other internet information.

\section{Framework of Survival and Recovery Strategy}

In order to analyze and develop strategies, two business phases have been arranged, namely the retrenchment phase and the recovery phase. 


\section{International Journal of Current Science Research and Review}

ISSN: 2581-8341

Volume 04 Issue 12 December 2021

DOI: 10.47191/ijcsrr/V4-i12-19, Impact Factor: 5.825

IJCSRR@ 2021

www.ijjcsrr.org

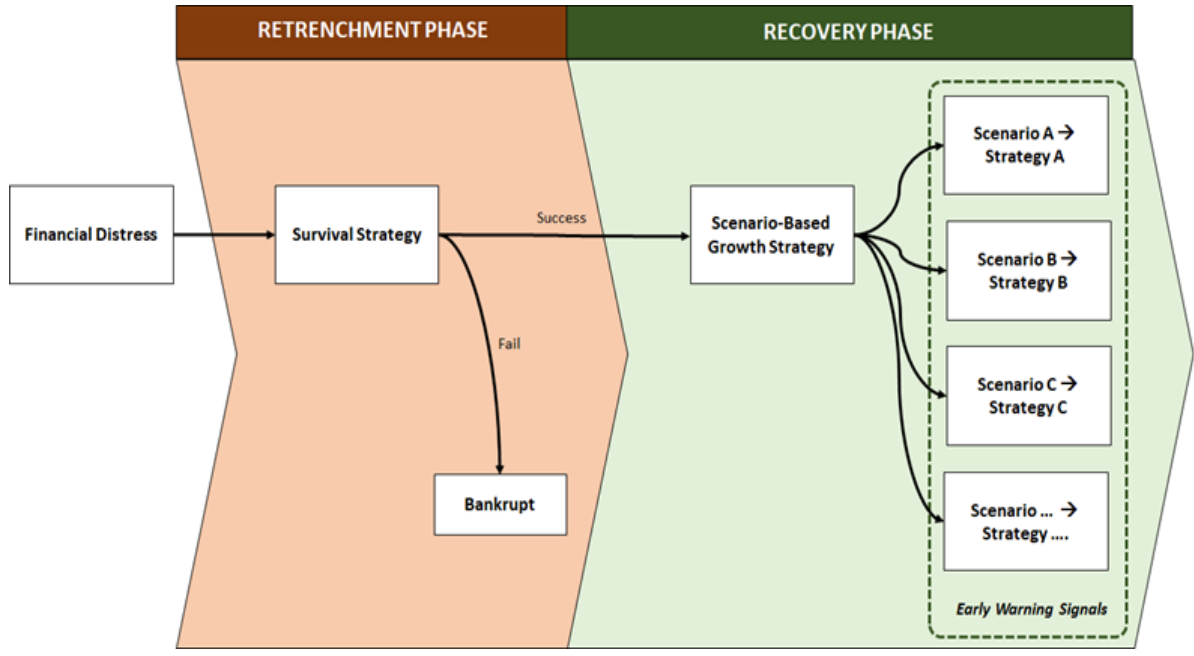

Figure 1. A Framework of Survival and Recovery Strategy

Retrenchment phase is initial response to turnaround situations for many firms consists of reduction in costs and assets. The primary objective for these reductions is to stabilize the performance decline in order to survive and have a positive cash flow. The recovery phase is the set of activities after the retrenchment stage that represents the long-term strategy. The objectives are long term profitability \& growth in the market. The recovery phase will be developed using scenario-based growth strategy (scenario planning). In this phase, scenario development will use interviews with the company's top management as well as key persons from external parties. Questions posed to interviewees included how the Covid-19 pandemic was affecting the aviation industry, what risks/uncertainty/factors are affecting MRO companies like GMF AeroAsia in the next 5 years, which are the driving forces that have high impact, and which are the driving forces that have a high level of uncertainty. Although at first glance it appears that the recovery phase can only be started after the retrenchment phase is complete, there is a possibility that some activities in the recovery phase can start during the retrenchment phase.

\section{Altman's Z" Score}

The formula of Emerging Market model approach is:

$$
\text { EM Score }(Z " \text { Score })=6.56\left(X_{1}\right)+3.26\left(X_{2}\right)+6.72\left(X_{3}\right)+1.05\left(X_{4}\right)+3.25
$$

Equation 1. Altman's Z"-Score Model for Emerging Market Company (Altman) where,

$X_{1}=$ Working Capital/Total Assets

$X_{2}=$ Retained Earnings/Total Assets

$X_{3}=$ Operating Income/Total Assets

$X_{4}=$ Book Value of Equity/Total Liabilities

\section{Debt ratio}

Debt ratio is calculated based on the definition of Aswath Damodaran, with a market value approach for equity and a book value approach for debt:

$$
\text { Debt Ratio }=\frac{\text { Total Debt }}{\text { Total Debt }+ \text { Market Equity }}
$$

Equation 2. Debt Ratio (Damodaran)

\section{FINDING AND DISCUSSION}

\section{Altman Z" Score}

Based on the financial report as of June 2021, the Z score is -0.04. Based on Altman's Z" Score, Equivalent Bond Rating, and Distress Zone table, GMF is included in the distress zone category and is equivalent to the D-rating in the bond. 


\section{International Journal of Current Science Research and Review}

ISSN: 2581-8341

Volume 04 Issue 12 December 2021

DOI: 10.47191/ijesrr/V4-i12-19, Impact Factor: 5.825

IJCSRR@ 2021

www.ijcsrr.org

\section{Debt Ratio}

Using the financial statements as of June 2021, the Debt Ratio is $72.27 \%$. GMF AeroAsia is included in the Aerospace/Defense industry category, where the average market debt ratio for the industry is $14.93 \%$. GMF Debt Ratio is $72.27 \%$ which is almost 5 times higher than Aerospace/Defense industry average and 2-3 times higher than all industry average. This shows that GMF is included in the overlevered category and the company may be at risk of default on its loans if interest rates suddenly rise. This shows that GMF needs to reduce its debt so that the company can run optimally to support future growth.

\section{Retrenchment Phase - Survival Strategy}

Based on Robins \& Pearce (1992), when a company is in distress condition, the suggestions for survival strategy are: Operational efficiency, Head count cuts, Liquidation, Divestment, and Product elimination. While from The Framework for Getting to The Optimal by Aswath Damodaran, if a company has a high debt ratio and is in danger of bankruptcy, then there are 3 things that can be done, including: Equity for debt swap, Sell assets, and Renegotiate with lenders. By concluding from the two discussions above, the options for survival strategy are:

Table 1. Retrenchment Phase - Survival Strategy

\begin{tabular}{|c|c|c|}
\hline Initiatives & Current Status & Considerations \\
\hline Head count cuts & $\begin{array}{l}\text { During the pandemic, GMF has stopped } \\
\text { recruitment and reduced third parties. }\end{array}$ & $\begin{array}{l}\text { i. Motivation of the remaining employees } \\
\text { ii. Anticipate a booming load after the re-activation of airline } \\
\text { operations and transfer loads from Halim Perdanakusuma } \\
\text { iii. Negotiation with trade unions for stabilization of the working } \\
\text { situation }\end{array}$ \\
\hline Operational Efficiency & $\begin{array}{l}\text { Currently, GMF is executing } \\
\text { improvements including business } \\
\text { process reengineering. }\end{array}$ & $\begin{array}{l}\text { i. Possible costs that arise } \\
\text { ii. How to encourage all related PICs to run the new business } \\
\text { process. }\end{array}$ \\
\hline Initiatives & Current Status & \begin{tabular}{|c|} 
Considerations \\
\end{tabular} \\
\hline $\begin{array}{l}\text { Product Elimination; } \\
\text { Liquidation \& } \\
\text { Divestment (Inc. M\&A) }\end{array}$ & $\begin{array}{l}\text { GMF has liquidated its subsidiary } \\
\text { named PT. GELKO and has continued } \\
\text { the process of selling inventory and } \\
\text { some non-essential assets. }\end{array}$ & $\begin{array}{l}\text { i. It is necessary to review the asset status, whether it is still in } \\
\text { banking collateral or not. } \\
\text { ii. It is necessary to review the short and long-term impact on the } \\
\text { company, especially if what is being done is the divestment of } \\
\text { subsidiary shares (currently GMF still has } 1 \text { active subsidiary named } \\
\text { PT. GDPS which has good performance) } \\
\text { iii. GCG aspects need to be secured } \\
\text { iv. Ensure that the assets sold are non-profitable and non-essential } \\
\text { assets }\end{array}$ \\
\hline Equity for debt swap & Still under study & $\begin{array}{l}\text { i. SOE's bureaucracy is known to be longer and more complicated } \\
\text { than that of the private sector, so sufficient anticipation is required } \\
\text { when conducting debt to equity swaps. } \\
\text { ii. It is necessary to convince GMF shareholders to be able to carry } \\
\text { out a debt to equity swap, because if the swap is carried out on } \\
\text { GMF's ownership shares, the current shareholder's shares will be } \\
\text { diluted. } \\
\text { iii. Considering the suitability of the new shareholder for GMF's } \\
\text { future business strategy (strategic fit) }\end{array}$ \\
\hline Renegotiate with lenders & $\begin{array}{l}\text { GMF has been in long negotiations } \\
\text { with vendors and banks since } 2020 \text { due } \\
\text { to cash flow difficulties }\end{array}$ & $\begin{array}{l}\text { i. Prioritization of vendors/banks } \\
\text { ii. The impact of the vendor's service or product on operations } \\
\text { iii. Common perspective between GMF and vendors/banks } \\
\text { iv. Future Cashflow } \\
\text { v. Strategic fit }\end{array}$ \\
\hline
\end{tabular}

\section{Recovery Phase - Growth Strategy using Scenario Planning}

There are 4 critical uncertainties and impacts that underlie scenarios creation. The modeling scenario used is not based on a 4-quadrant matrix as in Garvin \& Levesque, but is based on 4 possible futures referring to the modeling scenario in "Bandung Scenarios: Indonesia Energy Scenarios 2030". The 4 critical uncertainties and impacts that must be faced by the company, namely: 


\section{International Journal of Current Science Research and Review}

ISSN: 2581-8341

Volume 04 Issue 12 December 2021

DOI: 10.47191/ijcsrr/V4-i12-19, Impact Factor: 5.825

IJCSRR@ 2021

- Future Pandemic \& Government Policy of Air Travel \& Aviation Industry

- The result of PKPU Garuda Indonesia

- Support from lessors/suppliers/financial partners/landlords/airports

- Diversification Market Success Rate

Four (4) driving factors will form 4 scenarios called The Challenger Flight:
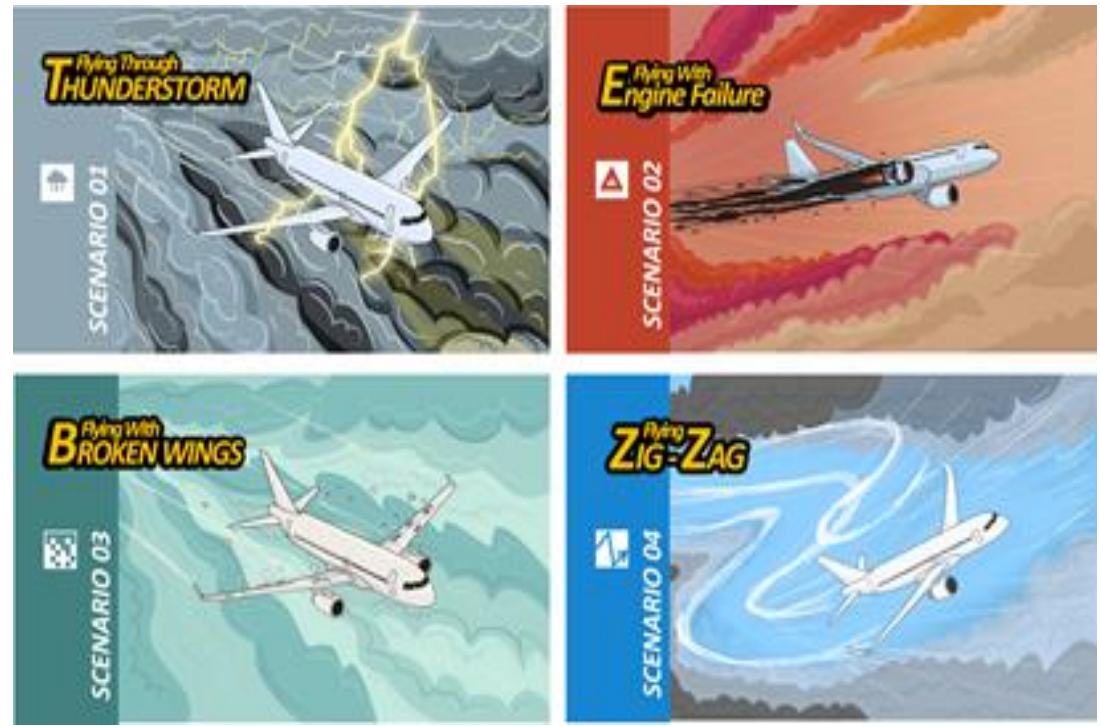

Figure 2. Four (4) Scenarios: The Challenger Flight

Scenario 1 - Flying Through Thunderstorm

This scenario is built based on the high uncertainty and impact on the Future Pandemic \& Government Policy of Air Travel \& Aviation Industry. In the future there is the possibility of another pandemic wave which is very difficult to predict when it will come (such as lightning) and will be followed by the issuance of government policies to limit air travel to minimize the impact of the wave. The economic growth path will be reducing fixed cost and investment risks, and continuing business diversification.

Scenario 2 - Flying with Engine Failure

This scenario is built on the high uncertainty and impact related to Garuda Indonesia's PKPU results. As the parent company and main customer of GMF, Garuda Indonesia is accounted for $50 \%$ of the company's revenue. Thus, if Garuda Indonesia goes bankrupt, then GMF will lose $50 \%$ of its captive revenue, just like an airplane that loses $50 \%$ of its thrust power (1 of 2 engines is failed). The economic growth will be reducing fixed cost and investment risks, and continuing business diversification. The economic growth path will be managing AR Garuda Indonesia, reduce costs and seek replacement revenue.

Scenario 3 - Flying with Broken Wings

Scenario 3 is built based on high uncertainty and impact related to vendor or supplier support as part of the business ecosystem. GMF has more than 100 vendors that support the company's business, including but not limited to material suppliers, labor service providers, landlords, financial partners (banks \& financial institutions), insurance companies, airports, electricity \& water providers, etc. If cashflow conditions are not ideal, there is a risk that vendors will withdraw support from GMF. The condition of vendors terminating support one by one is similar to the condition of the wing which is slowly collapsing. The economic growth path will be enhance collaboration within the business ecosystem \& efficiency.

Scenario 4 - Flying Zig-Zag

The fourth builds on the success level of Business Diversification. Currently, GMF has tried to diversify its business, adding military and industrial gas turbine services. However, the challenges faced to are quite high. One of the factors that trigger uncertainty arises 


\section{International Journal of Current Science Research and Review}

ISSN: 2581-8341

Volume 04 Issue 12 December 2021

DOI: 10.47191/ijcsrr/V4-i12-19, Impact Factor: 5.825

IJCSRR@ 2021

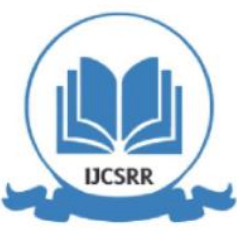

www.ijesrr.org

from the holding plan for Indonesian SOEs. There are several holding plans including the Defense Industry holding and the Energy Holding. There is a risk that aviation military maintenance work will only be absorbed by companies within the Defense Industry cluster, and so will the Energy Holding. This condition makes GMF must be able to adapt and change direction quickly if this happens, such as an airplane flying zig-zag. The economic growth will be partnership or establishment of GMF Group presence in other clusters/holdings.

Table 2. Recovery Phase - Growth Strategy based on 4 scenarios

\begin{tabular}{|c|c|c|}
\hline Scenario & Option (Strategy) & Early Warning Signals \\
\hline $\begin{array}{l}01 \text { - Flying } \\
\text { through } \\
\text { Thunderstorm }\end{array}$ & $\begin{array}{l}\text { - Increase proportion of variable cost } \\
\text { - Market penetration of cargo operators } \\
\text { - } \text { Offering aircraft-on-ground (prolong maintenance) services } \\
\text { - Government lobbying } \rightarrow \text { if air travel is restricted, then ask for a } \\
\text { - tax or customs relief policy } \\
\text { - Continuing business diversification }\end{array}$ & $\begin{array}{l}\text { - Increased Covid-19 infection rate } \\
\text { for new variants } \\
\text { - Air travel limitation policy applied } \\
\text { - Decreased fleet utilization }\end{array}$ \\
\hline $\begin{array}{l}02-\text { Flying } \\
\text { with Engine } \\
\text { Failure }\end{array}$ & $\begin{array}{l}\text { - Offset GA debt payment using their assets (Hangars, spare parts, } \\
\text { etc.) } \\
\text { - Measured support/service for Garuda Indonesia (reducing } \\
\text { Account Receivable) } \\
\text { - Downsizing } \\
\text { - Approach new airline (which will replace the Garuda Indonesia } \\
\text { route) }\end{array}$ & $\begin{array}{l}\text { - Debt payment obligations (PKPU) } \\
\text { approved by commercial court } \\
\text { - Agreements that were not reached } \\
\text { between GA and the vendor within } \\
\text { a certain period of time } \\
\text { - GA shareholder low } \\
\text { support/assistance }\end{array}$ \\
\hline $\begin{array}{l}03 \text { - Flying } \\
\text { with Broken } \\
\text { Wings }\end{array}$ & $\begin{array}{l}\text { - Collaboration with Indonesian Government to get a commitment } \\
\text { t from vendors (in order to support aviation and tourism holding, } \\
\text { as well as accelerate economic recovery) } \\
\text { - Approach to OEM for aircraft types owned by parent and sister } \\
\text { companies } \\
\text { - Back-to-back agreement between Customer-GMF-Vendor } \\
\text { - Joint Procurement with MRO partners (IAMSA) }\end{array}$ & $\begin{array}{l}\text { - Increasing Account Payable } \\
\text { - Vendors limit the support, even } \\
\text { proposing contract termination }\end{array}$ \\
\hline $\begin{array}{l}04 \text { - Flying Zig- } \\
\text { Zag }\end{array}$ & $\begin{array}{l}\text { - Close coordination with Ministry of SOE to gather updated } \\
\text { information } \\
\text { - Propose to Garuda Indonesia as the holding company to issue } \\
\text { new shares or sell part of their share ownership to companies in } \\
\text { Defense and or Energy Holdings } \\
\text { - Selling some portion of subsidiary shares to companies in } \\
\text { Defense and/or Energy Holdings } \\
\text { - Partnership } \rightarrow \text { joint capability }\end{array}$ & $\begin{array}{l}\text { - The process of forming a holding } \\
\text { is running smoothly } \\
\text { - Policy of inhouse maintenance } \\
\text { (intraholding) }\end{array}$ \\
\hline
\end{tabular}

\section{CONCLUSION}

Based on the research that has been performed, there are some conclusions to answer the research question in chapter 1. In order to maintain the company's going concern and future growth after Covid 19, two business phases have been arranged, namely the retrenchment phase and the recovery phase.

\section{The strategy to survive - Retrenchment Phase}

There are several steps that can be taken and/or continued by GMF including: Operational Efficiency, Head Count Cuts, Liquidation, Divestment, Product Elimination, Renegotiate with lenders and vendors, Equity for Debt Swap. The critical uncertainties that can impact the company's growth in the next 5 years are Future Pandemic \& Government Policy of Air Travel \& Aviation Industry, The result of PKPU Garuda Indonesia, Support from lessors/suppliers/financial partners/landlords/airports and Diversification Market Success Rate. 


\section{International Journal of Current Science Research and Review}

ISSN: 2581-8341

Volume 04 Issue 12 December 2021

DOI: 10.47191/ijesrr/V4-i12-19, Impact Factor: 5.825

IJCSRR@ 2021

www.ijesrr.org

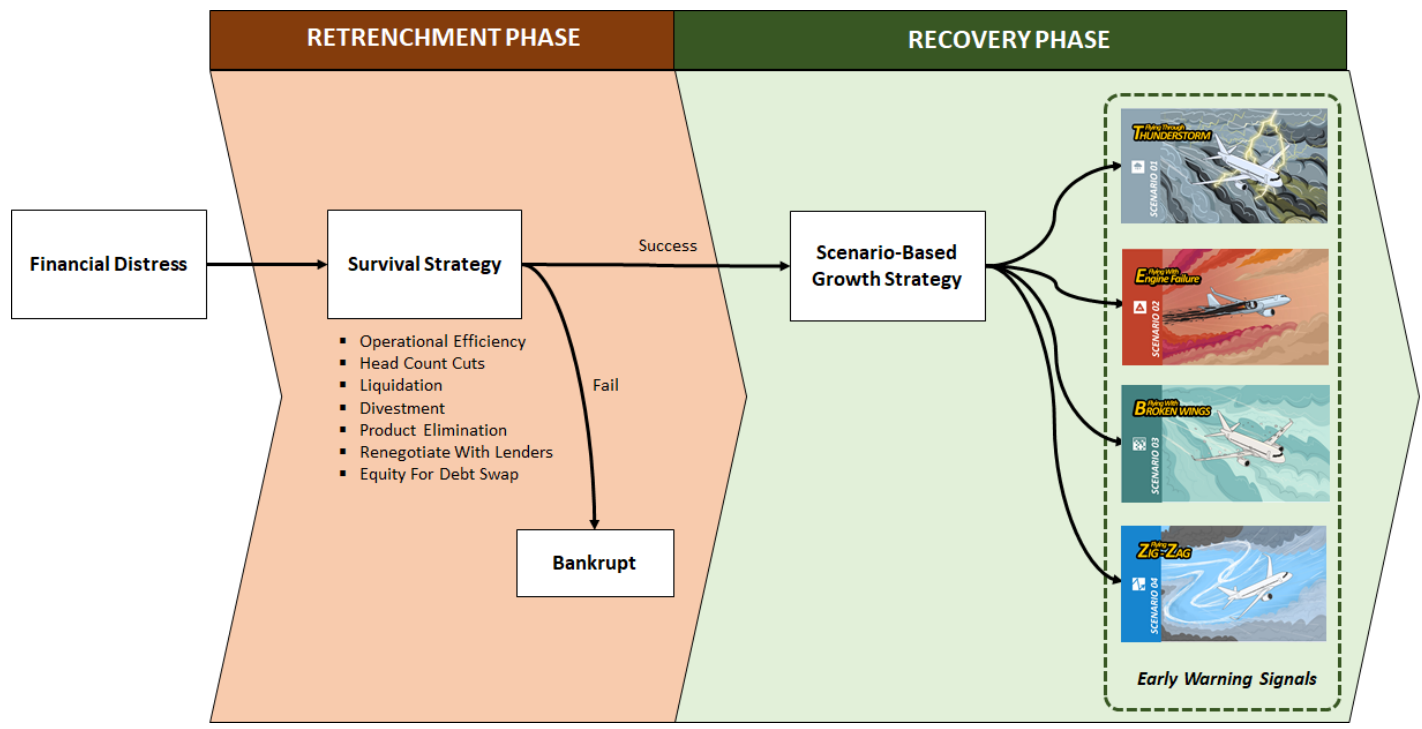

Figure 3. Summary Survival and Growth Strategy

The strategy to growth - Recovery phase

The possible scenarios of growth, to deal with uncertainty and rapid change in recovery phase are : Flying Through Thunderstorm which the strategy is reducing fixed cost and investment risks, and continuing business diversification; Flying with Engine Failure which the strategy is managing AR Garuda Indonesia, reduce costs and seek replacement revenue ; Flying with Broken Wings which the strategy is enhance collaboration within the business ecosystem \& efficiency; and the last is Flying Zig-Zag which the strategy is partnership or establishment of GMF Group presence in other clusters/holdings.

Despite the results, further research is needed considering several limitations of this study. First, It may be that only one or two initiatives must be continued or carried out, or it may be that all initiatives must be carried out in stages. Thus, further studies are needed to determine which initiatives are suitable to be carried out/continued and which are priorities, as well as to see how much impact they have on the company.

The execution of strategic choices during the retrenchment phase needs to also gain insight from shareholders and other stakeholders. Secondly, further studies are needed to estimate the financial impact of the 4 scenarios in the recovery phase.

\section{REFERENCES}

1. Altman, E. I. (2005). An Emerging Market Credit Scoring System for Corporate Bonds. Emerging Market Review.

2. Damodaran, A. (2014). Applied Corporate Finance.

3. Damodaran, A. (n.d.). Financial Ratios and Measures. Retrieved from https://pages.stern.nyu.edu/ adamodar/New_Home_Page/definitions.html

4. Darmawan, A., \& Supriyanto, J. (2018, March). The Effect of Financial Ratio of Financial Distress in Predicting Bankruptcy. Journal of Applied Managerial Accounting, 2.

5. Garvin, D. A., \& Levesque, L. C. (2006, July 31). A Note on Scenario Planning.

6. Johnson, G., Scholes, K., \& Whittington, R. (2008). Exploring Corporate Strategy (8th ed.). Essex, England: Pearson Education Limited.

7. Khaliq, A., Altarturi, B. H., Thaker, H. M., Harun, M. Y., \& Nahar, N. (2014, April). Identifying Financial Distress Firms : A Case Study of Malaysia's Government Linked Companies (GLC). International Journal of Economics, Finance, and Management.

8. Mulyanto, F. M., \& Sunitiyoso, Y. (2013). Scenario Planning Analysis for Startup Business Case Study: Kemilau Indonesia Magazine. The Indonesian Journal of Business Administration, 2, 562-570.

9. North, D. C. (1990). Institutions, Institutional Change, and Economic Performance. St. Louis: Cambridge University Press. 


\section{International Journal of Current Science Research and Review}

ISSN: 2581-8341

Volume 04 Issue 12 December 2021

DOI: 10.47191/ijesrr/V4-i12-19, Impact Factor: 5.825

IJCSRR@ 2021

www.ijcsrr.org

10. Nurhayati, Mufidah, A., \& Kholidah, A. N. (2017). The Determinants of Financial Distress of Basic Industry and Chemical Companies Listed in Indonesia Stock Exchange. Review of Management and Entrepreneurship, 01.

11. Platt, H. D., \& Platt, M. B. (2002). Predicting Corporate Financial Distress: Reflections on Choice-Based Sample Bias. Journal of Economics and Science, 184.

12. Porter, M. E. (1979, March). How Competitive Forces Shape Strategy. HBR Magazine.

13. Robins, D. K., \& Pearce, J. A. (1992, May). Turnaround : Retrenchment and Recovery. Strategic Management Journal, 13,287 - 309.

14. Rothaermel, F. T. (2021). Strategic Management 5e. New York, United States of America: McGraw-Hill Education.

15. Schoemaker, P. J. (1995). Scenario Planning: A Tool for Strategic Thinking. MIT Sloan Management Review, 36(2).

16. Schweizer, L., \& Nienhaus, A. (2017). Corporate distress and turnaround: integrating the literature and directing future research. Business Research. doi:http://dx.doi.org/10.1007/s40685-016-0041-8

17. Worldometer. (2021, October 16). Retrieved from worldometer.com

Cite this Article: R. Rendy Purwidyaputra (2021). Strategy Development for Survival \& Growth of MRO Company during \& Post Covid-19 Pandemic (Case Study: GMF Aeroasia). International Journal of Current Science Research and Review, 4(12), 1758-1765 